\title{
INDUCTIVE APPROACH IMPLEMENTATION TO IMPROVE THE MATHEMATICHAL REASONING, PROBLEM- SOLVING, AND SELF-CONCEPT OF JUNIOR HIGH SCHOOL STUDENTS IN KARAWANG DISTRICT
}

\author{
Yuli Mulyasari' ${ }^{1}$, Russefendi $^{2}$, Kustiana $^{3}$ \\ ${ }^{1}$ IKIP Siliwangi, Bandung \\ yuli.mulyasari12@gmail.com
}

\begin{tabular}{|c|c|}
\hline Penerimaan : 13 Juli 2018 & Diterima: 30 Desember 2018 \\
\hline
\end{tabular}

\begin{abstract}
ABSTRAK
Pendekatan Induktif merupakan alternatif yang ditawarkan untuk mengatasi permasalahan rendahnya kemampuan penalaran matematis, pemecahan masalah, dan konsep diri siswa. Populasi dalam penelitian ini adalah seluruh siswa SMP negeri di Kabupaten Karawang. Adapun sampel yang terpilih adalah siswa kelas VIII SMP Negeri 2 Pangkalan Kabupaten Karawang pada tahun ajaran 2017-2018. Pengambilan sampel dilakukan dengan teknik sampling, dalam random sampling diambil 1 kelas eksperimen dan 1 kelas kontrol. Hasil penelitian menunjukkan peningkatan kemampuan penalaran dan pemecahan masalah matematis siswa yang memperoleh pembelajaran dengan pendekatan induktif lebih baik daripada siswa yang memperoleh pembelajaran biasa. Konsep diri siswa yang memperoleh pembelajaran dengan pendekatan induktif lebih kecil atau sama dengan siswa yang memperoleh pembelajaran biasa. Asosiasi antara kemampuan penalaran dengan kemampuan pemecahan masalah matematis berada pada kategori sedang. Asosiasi antara kemampuan penalaran dengan konsep diri siswa berada pada kategori rendah. Asosiasi antara kemampuan pemecahan masalah dengan konsep diri siswa berada pada kategori rendah. Gambaran proses pembelajaran dengan Pendekatan Induktif sudah berjalan sesuai dengan sintaks pembelajaran dengan Pendekatan Induktif. Adapun kesulitan siswa dalam mengerjakan soal kemampuan penalaran dan pemecahan masalah matematis diantaranya, kesulitan mengidentifikasi keterkaitan antar konsep, kesulitan mengidentifikasi strategi yang dapat ditempuh, melaksanakan perhitungan, dan lengah dalam memeriksa kembali solusi yang diperoleh.
\end{abstract}

Kata kunci: pendekatan induktif, penalaran matematis, pemecahan masalah matematis, konsep diri.

\section{ABSTRACT}

Inductive Approach is an alternative that is offered to overcome the problem of low mathematical reasoning ability, problem-solving, and self-concept of students. The population in this study is all students of state SMP in Karawang district. The selected sample is for the students of class VIII SMP Negeri 2 Pangkalan, Karawang district in the academic year 2017-2018. Sampling was done by sampling technique, in random sampling was taken 1 experiment class and 1 control class. The result of the research shows improvement of reasoning ability and mathematical problem solving of students who gain learning with the inductive approach is better than students who get regular learning. The selfconcept of students acquiring learning with an inductive approach is smaller or equal to that of students who acquire regular learning. The association between reasoning ability and mathematical problem solving is in the moderate category. The association between reasoning ability and student self-concept is in a low category. The association between problem-solving ability and student self-concept is in a low category. The description of the learning process with the Inductive Approach is already in line with 
the syntax of learning with the Inductive Approach. As for the students' difficulties in working on problems of reasoning and problem solving, among others, the difficulty of identifying the interrelationships between concepts, the difficulty of identifying strategies that can be taken, carrying out calculations, and careless in re-examining the solutions obtained.

Keywords: inductive approach, mathematical reasoning, mathematical problem-solving, self-concept.

\section{PENDAHULUAN}

Dunia pendidikan terus menjadikan pengembangan kemampuan bernalar dan pemecahan masalah siswa menjadi bagian utama tujuan utamanya. Selaras dengan itu, penalaran berperan dalam membangun pengetahuan matematika siswa. Melalui kemampuan penalaran matematis, siswa berpikir sistematis dan logis sehingga sampai pada suatu kesimpulan dengan menggunakan argumen-argumen atau bukti-bukti yang kebenarannya sudah dibuktikan.

Salah satu tujuan pendidikan matematika lainnya adalah pemecahan masalah, bahkan kemampuan ini dikatakan sebagai jantungnya matematika. Hal itu berarti bahwa kemampuan pemecahan masalah matematis merupakan kemampuan dasar dalam belajar matematika.

Faktor penting yang mempengaruhi tercapainya tujuan pembelajaran matematika adalah siswa itu sendiri. Salah satunya adalah konsep diri yang dimiliki oleh siswa. Menurut Tan dan Yates (dalam Putri, 2013:20) bahwa: "Self-concept is an important construct in psychology and education especially academic self-concept which is generally defined as a person's perception of self with respect to achievement in school." Selain itu, menurut penelitian Zahra et al (2010) bahwa konsep diri siswa akan berkorelasi dengan pretasi belajar siswa. pada tiap-tiap model pembelajaran, prestasi belajar matematika siswa yang memiliki konsep diri tinggi lebih baik daripada siswa yang memiliki konsep diri sedang dan rendah sehingga ia merekomendasikan bahwa konsep diri akan berkorelasi dengan prestasi belajar sehingga diasumsikan akan berkorelasi pula dengan kemampuan penalaran dan pemecahan masalah matematis siswa.

Rendahnya kemampuan penalaran matematis siswa akan mempengaruhi kualitas belajar siswa, yang berdampak pula pada prestasi belajar siswa di sekolah. Hal ini terlihat dari hasil pembelajaran siswa yang tersirat dari hasil penelitian yang dilakukan oleh Sumarmo (Sukirwan, 2008:4) yang menyatakan bahwa skor kemampuan siswa dalam pemahaman dan penalaran masih rendah. Hal itu juga terlihat dari prestasi siswa dalam belajar matematika yang diungkapkan oleh hasil tes PISA 2006 yang menunjukkan bahwa Indonesia berada pada 
peringkat 52 dari 57 negara (Kusumah, 2011) dan mengingat pentingnya kemampuan berpikir tingkat tinggi dalam pembelajaran matematika masa kini.

Pembelajaran matematika yang mengarah kepada meningkatnya kemampuan penalaran dan pemecahan masalah matematis serta konsep diri siswa sudah semestinya diupayakan dan diimplementasikan. Alternatif yang ditawarkan untuk mengatasi masalah tersebut adalah pembelajaran menggunakan pendekatan induktif. Pembelajaran dengan pendekatan induktif berarti pembelajaran yang bermula dengan menyajikan sejumlah keadaan khusus kemudian dapat disimpulkan menjadi suatu konsep, prinsip atau aturan. Menurut penelitian Nafiah (2015), penerapan pendekatan induktif pada pembelajaran matematika dapat meningkatkan kemampuan penalaran matematis siswa. Kegiatan pembelajaran yang biasanya siswa terbiasa dengan pembelajaran yang berpusat pada guru berubah menjadi berpusat pada siswa dengan gagasangagasan yang mereka ungkapkan.

Tahapan pembelajaran dengan pendekatan induktif yang diungkapkan Huda (2015:78), bahwa tahapan pembelajaran induktif,

1. Tahap pembentukan konsep

a. Guru mengalkulasi dan membuat daftar.

b. Siswa mengelompokkan daftar.

c. Siswa membuat label dan kategori.

2. Tahap interpretasi data

a. Siswa mengidentifikasi relasi-relasi penting antarkategori.

b. Siswa mengeksplorasi relasi-relasi kategorial.

c. Siswa membuat kesimpulan.

3. Tahap penerapan prinsip

a. Siswa memprediksi konsekuensi, menjelaskan fenomena luar, menyusun hipotesis.

b. Siswa menjelaskan prediksi atau hipotesis.

c. Siswa menguji kebenaran (verifikasi) prediksi.

Penelitian ini bertujuan untuk mengetahui:

1. Peningkatan kemampuan penalaran matematis siswa SMP yang pembelajarannya menggunakan pendekatan induktif dibandingkan menggunakan pembelajaran biasa. 
2. Peningkatan kemampuan pemecahan masalah matematis siswa SMP yang pembelajarannya menggunakan pendekatan induktif dibandingkan menggunakan pembelajaran biasa.

3. Konsep diri siswa SMP yang pembelajarannya menggunakan pendekatan induktif dibandingkan menggunakan pembelajaran biasa.

4. Asosiasi antara:

a. Kemampuam penalaran dengan pemecahan masalah matematis siswa SMP yang menggunakan pendekatan induktif.

b. Kemampuan penalaran matematis dengan konsep diri siswa SMP yang menggunakan pendekatan induktif.

c. Kemampuan pemecahan masalah matematis dengan konsep diri siswa SMP yang menggunakan pendekatan induktif.

5. Gambaran kesulitan siswa dalam menyelesaikan soal-soal penalaran dan pemecahan masalah matematis.

\section{METODE PENELITIAN}

Penelitian ini merupakan penelitian eksperimen yaitu penelitian yang digunakan untuk mencari hubungan antara treatment dalam hal ini pembelajaran terhadap kelompok yang diberi perlakuan yang disebut kelompok eksperimen dan sebagai pembanding digunakan kelompok kontrol yang menggunakan pembelajaran biasa. Disain penelitian yang digunakan adalah sebagai berikut:

$\begin{array}{llll}\text { A } & \text { O } & X & O \\ \text { A } & \text { O } & & \text { O }\end{array}$

Keterangan:

A : Pengambilan sampel secara acak kelas

$\mathrm{O} \quad$ : Instrumen pretes $=$ instrumen postes kemampuan penalaran dan pemecahan masalah matematis siswa

X : Pendekatan Induktif

Instrumen yang digunakan dalam penelitian ini berupa tes dan non tes. Instrument tes terdiri dari pretest dan postes sedangkan instrument non tes berupa angket konsep diri. Analisis data yang digunkaan dalam penelitian ini yaitu analisis butir soal untuk mengetahui kualitas soal yang akan digunakan. Analisis butir soal yang dimaksudkan adalah validitas, reliabilitas, taraf kesukaran, dan daya pembeda. Analisis peningkatan kemampuan penalaran dan pemecahan masalah matematis siswa 
menurut Hake (1999) berdasarkan pretes dan postes menggunakan rumus gain ternormalisasi. Analisis uji dua rerata konsep diri menggunakan uji Mann Whitney. Serta analisis asosiasi antar variabel kemampuan menggunakan crosstab.

\section{HASIL DAN PEMBAHASAN}

Pelaksanaan pembelajaran pada penelitian ini dilakukan sebanyak 10 kali pertemuan. Pertemuan pertama pelaksanaan pretest, sebanyak 8 pertemuan dilaksanakan pembelajaran menggunakan pendekatan induktif, dan pertemuan terakhir pemberian postes dan angket konsep diri.

Analisis peningkatan kemampuan penalaran matematis antara siswa yang memperoleh pembelajaran dengan pendekatan induktif dengan siswa yang memperoleh pembelajaran biasa dianalisis menggunakan uji Mann Whitney. Hasil uji dua rerata tersaji dalam Tabel 1.

Tabel 1. Uji Perbedaan Dua Rerata Peningkatan Kemampuan Penalaran Matematis

\begin{tabular}{lr}
\hline & \multicolumn{2}{c}{ Gain Kemampuan } \\
& Penalaran Matematis \\
\hline Mann-Whitney U & 266.000 \\
Wilcoxon W & 932.000 \\
Z & -4.303 \\
Asymp. Sig. (2-tailed) & .000 \\
\hline a. Grouping Variable: Pendekatan Pembelajaran
\end{tabular}

Berdasarkan hasil pengolahan data yang disajikan pada Tabel 1, dapat disimpulkan bahwa peningkatan kemampuan penalaran matematis memiliki nilai sig $\frac{0,00}{2}=0,00$, ini berarti peningkatan kemampuan penalaran matematis siswa yang memperoleh pembelajaran dengan pendekatan induktif lebih baik daripada siswa yang memperoleh pembelajaran biasa.

Analisis peningkatan kemampuan pemecahan masalah matematis antara siswa yang memperoleh pembelajaran dengan pendekatan induktif dengan siswa yang memperoleh pembelajaran biasa dianalisis menggunakan uji Mann Whitney. Hasil uji dua rerata tersaji dalam Tabel 2.

Tabel 2. Uji Perbedaan Dua Rerata

Peningkatan Kemampuan Pemecahan Masalah Matematis

Gain Kemampuan

Pemecahan Masalah Matematis

\begin{tabular}{lr}
\hline Mann-Whitney U & 480.500 \\
Wilcoxon W & 1146.500
\end{tabular}


$\begin{array}{lr}\mathrm{Z} & -1.887 \\ & .059\end{array}$

a. Grouping Variable: Pendekatan Pembelajaran

Berdasarkan hasil pengolahan data yang disajikan pada Tabel 2, dapat disimpulkan bahwa peningkatan kemampuan pemecahan masalah matematis memiliki nilai sig $\frac{0,059}{2}=0,03$, ini berarti peningkatan kemampuan pemecahan masalah matematis siswa yang memperoleh pembelajaran dengan pendekatan induktif lebih baik daripada siswa yang memperoleh pembelajaran biasa.

Analisis konsep diri siswa yang memperoleh pembelajaran dengan pendekatan induktif dengan siswa yang memperoleh pembelajaran biasa dianalisis menggunakan uji Mann Whitney. Hasil uji dua rerata tersaji dalam Tabel 3.

Tabel 3. Uji Perbedaan Dua Rerata Konsep Diri

\begin{tabular}{lr}
\hline & Konsep Diri \\
\hline Mann-Whitney U & 552.000 \\
Wilcoxon W & 1218.000 \\
$Z$ & -1.082 \\
Asymp. Sig. (2-tailed) & .279 \\
\hline a. Grouping Variable: Pendekatan Pembelajaran
\end{tabular}

Berdasarkan hasil pengolahan data yang disajikan pada Tabel 3, dapat disimpulkan bahwa konsep diri siswa memiliki nilai sig $\frac{0,279}{2}=0,14$, ini berarti konsep diri siswa yang memperoleh pembelajaran dengan pendekatan induktif lebih kecil atau sama dengan siswa yang memperoleh pembelajaran biasa.

Analisis asosiasi antara kemampuan penalaran matematis dengan kemampuan pemecahan masalah matematis siswa yang memperoleh pembelajaran dengan pendekatan induktif dengan siswa yang memperoleh pembelajaran biasa dianalisis menggunakan uji asosiasi kontingensi.

Tabel 4. Uji Asosiasi Kontingensi Kemampuan Penalaran dan Pemecahan Masalah Matematis

\begin{tabular}{llrr}
\hline & & Value & Approx. Sig. \\
\hline Nominal by & Contingency & .363 & .242 \\
Nominal & Coefficient & 36 & \\
N of Valid Cases & & & \\
\hline
\end{tabular}

a. Not assuming the null hypothesis.

b. Using the asymptotic standard error assuming the null hypothesis. 
Berdasarkan Tabel 4, terdapat skor koefisien kontingensi C adalah 0,363. Dibandingkan dengan skor $C_{\text {maks }}=0,816$

Selanjutnya akan dihitung skor $\boldsymbol{Q}$ sebagai berikut.

$$
Q=\frac{C}{C_{\text {maks }}}=\frac{0,363}{0,816}=0,445
$$

Berdasarkan skor $\boldsymbol{Q}$ yang diperoleh yaitu maka disimpulkan bahwa derajat asosiasi antara kemampuan penalaran matematis dengan kemampuan pemecahan masalah matematis tergolong asosiasi sedang. Analisis asosiasi antara kemampuan penalaran matematis dengan konsep diri siswa yang memperoleh pembelajaran dengan pendekatan induktif dengan siswa yang memperoleh pembelajaran biasa dianalisis menggunakan uji asosiasi kontingensi.

Tabel 5. Uji Asosiasi Kontingensi Kemampuan Penalaran Matematis dan Konsep Diri

\begin{tabular}{llrr}
\hline & & Value & Approx. Sig. \\
\hline Nominal by & Contingency & .243 & .687 \\
Nominal & Coefficient & 36 & \\
N of Valid Cases & & & \\
\hline
\end{tabular}

a. Not assuming the null hypothesis.

b. Using the asymptotic standard error assuming the null hypothesis.

Berdasarkan Tabel 5, terdapat skor koefisien kontingensi C adalah 0,243. Dibandingkan dengan skor $C_{\text {maks }}=0,816$. Selanjutnya akan dihitung skor $\boldsymbol{Q}$ sebagai berikut.

$$
\boldsymbol{Q}=\frac{\boldsymbol{C}}{\boldsymbol{C}_{\text {maks }}}=\frac{0,243}{0,816}=0,298
$$

Berdasarkan skor $\boldsymbol{Q}$ yang diperoleh yaitu maka disimpulkan bahwa derajat asosiasi antara kemampuan penalaran matematis dengan konsep diri tergolong asosiasi rendah. Analisis asosiasi antara kemampuan pemecahan masalah matematis dengan konsep diri siswa yang memperoleh pembelajaran dengan pendekatan induktif dengan siswa yang memperoleh pembelajaran biasa dianalisis menggunakan uji asosiasi kontingensi.

Tabel 6. Uji Asosiasi Kontingensi

Kemampuan Pemecahan Masalah Matematis dan Konsep Diri

\begin{tabular}{llcr}
\hline & & Value & Approx. Sig. \\
\hline Nominal by & Contingency & .181 & .874 \\
Nominal & Coefficient & &
\end{tabular}


$\mathrm{N}$ of Valid Cases

a. Not assuming the null hypothesis.

b. Using the asymptotic standard error assuming the null hypothesis.

Berdasarkan Tabel 6, terdapat skor koefisien kontingensi C adalah 0,181. Dibandingkan dengan skor $C_{\text {maks }}=0,816$. Selanjutnya akan dihitung skor $\boldsymbol{Q}$ sebagai berikut.

$$
\boldsymbol{Q}=\frac{\boldsymbol{C}}{\boldsymbol{C}_{\text {maks }}}=\frac{0,181}{0,816}=0,221
$$

Berdasarkan skor $\boldsymbol{Q}$ yang diperoleh yaitu maka disimpulkan bahwa derajat asosiasi antara kemampuan pemecahan masalah matematis dengan konsep diri tergolong asosiasi rendah. Hasil Uji Mann Whitney menunjukkan nilai signifikansinya lebih kecil dari taraf signifikansi yang digunakan maka $H_{0}$ ditolak yang artinya peningkatan kemampuan penalaran matematis siswa yang memperoleh pembelajaran dengan pendekatan induktif lebih baik daripada siswa yang memperoleh pembelajaran biasa.

Kebutuhan siswa untuk meningkatkan kemampuan penalaran dapat terbiasa dilakukan dengan pendekatan induktif. Sedangkan pembelajaran yang biasa dilaksanakan tidak terfokuskan pada peningkatan hardskill dan softskill matematis siswa seperti halnya fokus dalam meningkatkan kemampuan penalaran matematis siswa. Berdasarkan data dan fakta yang ditemukan dalam penelitian ini menunjukkan bahwa kemampuan penalaran matematis dapat meningkat dengan menggunakan pendekatan Induktif. Hal ini sejalan dengan penelitian yang dilakukan oleh Winarto (2014) yang menyimpulkan bahwa pendekatan induktif mampu membangun kemampuan berpikir tingkat tinggi siswa. Lebih khususnya, Aisyah (2016) mengungkapkan bahwa kemampuan generalisasi mampu ditingkatkan melalui pendekatan induktif.

Hasil Uji Mann Whitney menunjukkan nilai signifikansinya lebih kecil dari taraf signifikansi yang digunakan maka $H_{0}$ ditolak yang artinya peningkatan kemampuan pemecahan masalah matematis siswa yang memperoleh pembelajaran dengan pendekatan induktif lebih baik daripada siswa yang memperoleh pembelajaran biasa.

Berdasarkan data dan fakta yang ditemukan dalam penelitian ini menunjukkan bahwa kemampuan pemecahan masalah matematis dapat meningkat dengan menggunakan pendekatan Induktif. Hal ini sejalan dengan penelitian yang dilakukan oleh Winarso (2014) yang 
menyimpulkan bahwa bahwa pendekatan induktif mampu membangun kemampuan berpikir tingkat tinggi siswa.

Hasil Uji Mann Whitney menunjukkan nilai signifikansinya lebih besar dari taraf signifikansi yang digunakan maka $H_{0}$ diterima yang artinya konsep diri siswa yang memperoleh pembelajaran dengan pendekatan induktif lebih kecil atau sama dengan siswa yang memperoleh pembelajaran biasa.

Berdasarkan hasil penelitian dengan menggunakan uji asosiasi kontingensi menunjukkan bahwa asosiasi antara kemampuan penalaran matematis dengan kemampuan pemecahan masalah matematis termasuk asosiasi sedang. Artinya tingkat kemampuan penalaran matematis memiliki kecenderungan dengan tingkat kemampuan pemecahan masalah yang sama. Namun masih terdapat tingkat kemampuan penalaran matematis yang tidak memiliki kecenderungan pada salah satu tingkat kemampuan pemecahan masalah matematis.

Hal ini terlihat bahwa kemampuan penalaran matematis sedang cenderung mempunyai kemampuan pemecahan masalah yang sedang juga. Kemampuan penalaran matematis tinggi cenderung mempunyai kemampuan pemecahan masalah matematis yang tinggi juga. Namun kemampuan penalaran matematis rendah tidak memiliki kecenderung pada salah satu tingkat kemampuan pemecahan masalah matematis.

Asosiasi antara kemampuan penalaran matematis dengan konsep diri siswa termasuk asosiasi rendah. Hal tersebut pun sejalan dengan asosiasi antara kemampuan pemecahan masalah dengan konsep diri siswa yang hasilnya menunjukan asosiasi rendah. Setiap tingkat kemampuan penalaran dan pemecahan masalah matematis didominasi oleh konsep diri sedang. Ini menunjukkan bahwa tidak ada konsistensi asosiasi antara kemampuan kognitif dengan afektif matematis. Hal tersebut bertentangan dengan hasil penelitian Zahra et al (2010), bahwa pada tiap-tiap model pembelajaran, prestasi belajar matematika siswa yang memiliki konsep diri tinggi lebih baik daripada siswa yang memiliki konsep diri sedang dan rendah sehingga ia merekomendasikan bahwa konsep diri akan berkorelasi dengan prestasi belajar sehingga diasumsikan akan berkorelasi pula dengan kemampuan penalaran dan pemecahan masalah matematis siswa.

Kesulitasn siswa dalam mengerjakan soal kemampuan penalaran dan pemecahan masalah matematis diantaranya: 1) siswa yang tidak mampu mengerjakan soal ini dengan sempurna kurang memahami kaitan antar konsep antara triple Pythagoras yang tersirat dengan garis 
singgung yang diketahui. Mungkin ini disebabkan karena kebiasaan siswa yang berasumsi bahwa setiap bab dalam pembelajaran matematika hanya sekedar bab per bab. Padahal materimateri dalam pembelajaran matematika saling terintegrasi, dengan kata lain bab awal menjadi prasyarat materi yang selanjutnya. beberapa siswa merasa kebingungan dengan penjelasan jawaban yang dikemukakan; 2) beberapa siswa merasa kebingungan dengan penjelasan jawaban yang dikemukakan, siswa kesulitan menuliskan model matematika untuk mengungkapkan jawaban; 3) beberapa siswa merasa kesulitan dalam mengerjakan soal ini karena tidak mampu menggambarkan situasi yang diketahui. Selain itu siswa tidak mampu mengidentifikasi kecenderungan konsep dalam soal; 4) beberapa siswa karena tidak mampu menggambarkan situasi yang diketahui. Selain itu siswa tidak mampu mengidentifikasi kecenderungan konsep dalam soal; 5) sejak awal hampir semua siswa mengalami kesulitan mengkonstruksi soal cerita kedalam pemodelan matematika, siswa tidak menyelesaikan perhitungan. Selain itu mereka kesulitan dalam memberikan penjelasan atas jawabannya sehingga mereka sulit untuk membuat kesimpulan;

\section{KESIMPULAN}

Peningkatan kemampuan penalaran matematis siswa yang memperoleh pembelajaran dengan pendekatan induktif lebih baik daripada siswa yang memperoleh pembelajaran biasa. Siswa perlu dilatih untuk menyelesaiakan soal kemampuan penalaran matematis. Sebab, kemampuan ini merupakan salah satu tujuan pembelajaran matematika.

Peningkatan kemampuan pemecahan masalah matematis siswa yang memperoleh pembelajaran dengan pendekatan induktif lebih baik daripada siswa yang memperoleh pembelajaran biasa. Siswa perlu dilatih untuk menyelesaiakan soal kemampuan pemecahan masalah matematis. Sebab, kemampuan ini merupakan salah satu tujuan pembelajaran matematika.

Konsep diri siswa yang memperoleh pembelajaran dengan pendekatan induktif lebih kecil atau sama dengan siswa yang memperoleh pembelajaran biasa. Siswa perlu dimotivasi agar memiliki konsep diri positif yang tinggi agar mempunyai jiwa kompetititf yang tinggi, kesetaraan diri, dan mempunyai sikap yang tepat terhadap pujian maupun kritikan. 


\section{REFERENSI}

AZ Zahra, AY, \& Yusuf, MI (2010, March 01). "Relationship of Academic, Physical and Social Self-Concepts of Students with Their Academic Achievement". In Contemporary Issues In Education Research, Vol 03 - No. 3.

Aisyah, A. (2016). Literature Study: Inductive Approach to Increase the Capability of Generalization and Self Confidence of Vocational School Students. Journal of Research on Education and Teaching Mathematics (JP3M), 1-12.

Hake, R.R 1999. Analyzing Change/Gain Scores. [Online]. Tersedia di: www.phsicsIndiana.edu/sdi/analyzingchange-gain.pdf (diunduh tanggal 13 Januari 2014)

Huda, M. (2015). Teaching and Learning Models. Yogyakarta: Student Literature.

Princess, FM (2013, April 01). Journal of Edumatica. The Influence of Realistic Mathematics Learning to the Ability of Mathematical Reasoning of Junior High School Students, Vol. 03 - No. 1.

Winarto, B. (2016). Developing the Ability of Reasoning and Creative Thinking as well as the Independence of Mathematical Learning of Junior High School Students through a Guided Invention Approach. Thesis STKIP Siliwangi. Bandung: Not Published 